\title{
THE IMPACT OF ENTREPRENEURIAL ORIENTATION AND COLLABORATIVE NETWORKS ON CREATIVE INDUSTRIES PERFORMANCE
}

\author{
Mulyana ${ }^{\varpi}$, Sutapa \\ Faculty of Economics, Islam Sultan Agung University, Semarang, Indonesia
}

Info Article

History Article:

Received Juny 2016

Approved August 2016

Published September 2016

Keywords:

Collaborative Networks;

Entrepreneurial Orientation;

Innovation Capabilities;

Competitive Advantage;

Performance

\begin{abstract}
Creative industries significantly contribute to Indonesia economic development. There are many problems faced especially in improving innovation capabilities and competitive advantages. This study proposes to examine the effect of collaborative networks and entrepreneurial orientation to innovation capabilities, competitivee advantage and performance. Some creative industries located at several cities in the Central Java Province. Sampling methods used in this study is purposive sampling and data is analyzed by the multiple linier regressions. The result of this study shows that entrepreneurial orientation significantly affects both the innovation capability and performance. Collaborative networks significantly affects both the innovation capability and competitive advantage. Furthermore, the result shows that entrepreneurial orientation, innovation capability and competitive advantage significantly affect the performance. Nevertheless, it shows that collaborative networks do not significantly affect the performance.
\end{abstract}

\section{DAMPAK ORIENTASI KEWIRAUSAHAAN DAN KOLABORASI JEJARING TERHADAP KINERJA INDUSTRI KREATIF}

\begin{abstract}
Abstrak
Industri kreatif secara signifikan berkontribusi terhadap pembangunan ekonomi Indonesia. Untuk lebih mengembangkan industri kreatif masih banyak masalah yang harus ditangani terutama berkaitan dengan meningkatkan kapabilitas inovasi dan keunggulan bersaing mereka. Industri kreatif terletak di beberapa kota di Propinsi Jawa Tengah. Metode pengambilan sampel menggunakan purpusive sampling dan analisis data menggunakan regresi linier berganda. Hasil studi menunjukkan bahwa orientasi kewirausahaan berpengaruh signifikan terhadap kapabilitas inovasi dan kinerja. Collaborative networs berpengaruh signifikan terhadap kapabilitas inovasi dan keunggulan bersaing. Selanjutnya hasil studi juga menunjukkan bahwa orientasi kewirausahaan, kapabilitas inovasi dan keunggulan bersaing berpengaruh signifikan terhadap kinerja. Akan tetapi hasil studi ini menunjukkan bahwa collaborative networs tidak berpengaruh signifikan terhadap kinerja.
\end{abstract}

JEL Classification: L2, L26

$\begin{array}{lr}{ }^{\circledR} \text { Correspondence Address } & \text { ISSN } \\ \text { Terboyo Wetan, Genuk, Terboyo Kulon, Genuk, } & 2086-0668 \text { (print) } \\ \text { Kota Semarang, Jawa Tengah 50112 } & 2337-5434 \text { (online) } \\ \text { Email: mulyana@unissula.ac.id } & \end{array}$

Email: mulyana@unissula.ac.id 
Mulyana \& Sutapa / The Impact Of Entrepreneurial Orientation and Collaborative Networks ...

\section{INTRODUCTION}

Creative industry is one of the sectors that supports the economic development of Indonesia, particularly contributes to the gross domestic income, and provides employment. In 2025 creative industry is expected contributing 11 percent to the gross domestic product (GDP) and about 12-13 percent of the total exports (Ministry Industry and Trade, 2008). The greater role of creative industries for economic development needs the more supports from many parties. The problem faced today is the quality of human resources especially with weak collaborative network building and entrepreneurial orientation which further impact on innovation capabilities, competitive advantage and business performance.

The creative economic significantly contributesto the gross domestic product (GDP) and creates the added value every year. It also significantly absorbed the employee in 2011 reaching 11.51 million people and in 2012, it increased up to 11.57 million people. While the number of business sectors of the creative economy in 2010 reached 5.5 million, include the craft sector for $20.3 \%$, or 1.07 million, the fashion of $20.1 \%$ or 1.06 million and the largest dominant business sector, the culinary sector is $56.5 \%$ or 2.797 million (Department of cooperative and SMEs, 2008).

Creative industries are part of the Micro, Small and Medium Enterprises (SMEs), and its development has not been optimal yet. The development of creative industry can be seen from the growing number of business units and employment over the last five years (2011-2015), which is still very small, where the number of SMEs growth in Central Java Average is only $0.07 \%$ and in employment is $0.08 \%$ (Department of Cooperatives and SMEs, 2015).

Creativity and innovation have important role to the creative industry in order to create a competitive advantage, therefore, businesses must change the paradigm-based way of thinking of art into a performance-based entrepreneurs. A good creative industry business should have the ability to take the challenge, competitive, strategic and a strong desire in reaching the achievement business (Halim, 2011). Business competition in the creative industries is getting tighter so it needs competitive advantage to go forward and expand it. In facing the free-market, creative industries should develop its creativity and innovation through a learning process, transferring knowledge and technology in accordance with the dynamics of the environment. The ability to innovate is expected to create competitive advantage and a sustainable performance. Competition in the global market does not only rely on price and quality, but also the basis of technology, innovation, creativity and imagination (Esti \& Suryani, 2008).

Some important factors in competitive advantage are by performing a variety of innovation (products, markets, services) in order to meet market demands. Competitive advantage exhibiting companies performs better than competitors in the same industry (Hasan, 2008). Competitive advantage can be created if the creative industries are able to provide good quality products based on consumer tastes and faster than the competition. Furthermore, the competitive advantage and sustained performance can be achieved if creative industries are able to innovate continuously based on the environment dynamics. Competitive advantage will improve business performance (Suzana, 2014).

The development of effective innovation requires adequate resources, both in human resources, finance, technology, so that the creative industries will be able to build excellent collaborative networks. Business incubator as a center of information access can boost collaborative networks between organizations to develop new technology innovation and entrepreneurship. Collaborative networks is potential to build synergies that will help new technology innovation and commercialization activities (Ziemer \& Long, 2009)

The rapid environmental change, especially in the field of technology forces creative industries to promote creativity and innovation 
based on technological developments. Increasing competitive advantage must soon be realized in order to compete in the global market, particularly in facing the implementation of the Asean Economic Community (AEC). Improving the ability of the organization through the process of learning, knowledge and technology transfer through collaborative networks is an effective way to develop innovation. Therefore, entrepreneurial orientation for the creative industries supported by good collaborative networks is solution to crate innovation, a competitive advantage and sustainable performance.

Some previous studies indicate that the collaboration between the academic, government, corporate and civil society is able to drive innovation for creative people that promote economic growth (Afonso et al., 2012). Study in Malaysia shows that intellectual collaboration, government and business are also able to improve the performance of the creative industries (Ministry Industry \& Trade, 2008). Collaborative networks are designed to define an innovation strategy to assess the competence of the external network partners include universities, companies, and governments (Carayannis \& Campbell, 2009; Varrichio et al., 2012).

Collaborative network is a source of creative development of innovation in the food industry (Najib et al., 2014). Collaborative networks have good to build synergy in the development of technological innovation (Ziemer \& Long, 2009). Other studies show that collaborative communication can improve financial performance, the performance of cooperation with customers (Chen et al., 2013), and networks capability significantly moderate the relationship between entrepreneurial orientation and business performance (Zhang \& Zhang, 2012). While other studies show different results, that collaborative network does not significantly affect organizational performance (Ofem, 2014), as well as small company's internal cooperation with the government cannot improve innovation performance (Zeng et al., 2010).

This study focuses on the influence of collaborative networks and entrepreneurial orien- tation towards innovation capabilities, competitive advantage and performance of the creative industries. The role of collaborative networks and entrepreneurial orientation in supporting the development of innovation and competitive advantage and sustainable performance. The findings of this study are expected to contribute in the development of creative industries in order to face the MEA so as to compete in the global market.

\section{Hypothesis Development \\ Relationship between Collaborative Networks and Capability Innovation}

Collaborative networks are designed to define an innovation strategy to assess the competence of partners external network that includes universities, companies, and governments (Carayannis \& Campbell, 2009; Varrichio et al., 2012), while cooperation with various partners will increase innovation for a wide range of shared knowledge (Tsai, 2009). The dynamics of business relationships are very complex and encourage companies improve their strategic collaboration to develop innovations that can generate value for each member (Sakmoto et al., 2010).

Collaborative networks significantly affect the development of innovation (Zheng \& Zhao, 2013; Najib et al., 2014). Collaborative networks develop network model for the innovation development, which includes four variables that describe a collaborative network, including suppliers, clients, competitors, and research organizations (Tsai, 2009). Collaborative network is a vertical network consisting of clients, suppliers and other companies (competitors) and horizontal network consisting of research institutes, universities, and government (Zeng et al., 2010). Innovation defines the way business cooperate people, ideas and resources to produce creativity and innovation (Sousa, 2012).

The local government plays an important role in collaborating local partnership (Everingham et al., 2011), there is a negative relationship institutional governance that regulates 
Mulyana \& Sutapa / The Impact Of Entrepreneurial Orientation and Collaborative Networks ...

the cooperation with the success of technology innovation (Boland et al., 2012). Collaborative networks have the potential to build synergy in the technological innovation development (Ziemer \& Long, 2009). Institutional network has a stronger effect than the market network to product innovation, while the network market has positive impact on organizational innovation (Kim \& Lui, 2015).

H1: Collaborative networks significantly affect innovation capabilities

\section{Relationship between Entrepreneurial Orienta- tion and Capability Innovation}

Several studies show that entrepreneurial orientation has an important role in enhancing innovation capabilities and performance of the company. Entrepreneurship significantly effect on innovation capabilities (Lee \& Hsieh, 2010). Innovation capability mediates the relationship between the entrepreneurial orientation with the success of the project (Parkman et al., 2012). Entrepreneurial orientation can improve innovation performance (Parkman et al., 2012; Paulina \& Wardoyo, 2012; Khalili et al., 2013). The different entrepreneur social capital can improve complexity concentration of the innovation model (Xu Yang, 2011). Management supports the entrepreneurial-oriented companies to innovate (Maatoofi \& Tajedddini, 2011).

$\mathrm{H} 2$ : Entrepreneurial orientation significantly affect innovation capabilities

\section{Relationship between Collaborative Networks and Competitive Advantage}

Competitive advantage can be achieved through investment cooperation, knowledge sharing and effective management (Doina et al., 2012). The best competitive advantage in a business largely depends on the ability of the company's resources. The network connection through the incorporation of knowledge, skills and resources can build competitive advantage through specialization, collaboration and increased flexibility (Kolakovic \& Milovanovic, 2010), on the contrary collaborative networks in the SME food has no significant effect on the competitive advantage (Najib et al., 2014).

Competitive advantage shows that a company can do better than other companies even if they are in same industrial environment (Hassan, 2008). Social networking as a marketing strategy for small and medium enterprises (Vasques, 2014), and as a competitive force that is determined by the interaction of the actors in networks (Awauh, 2008). Collaborative communication can improve marketing and market relations capacity (Chen et al., 2013). External and internal knowledge sharing networks are able to create an excellence corporate (Kennel \& Giround, 2015).

International network size is capable of creating a network characteristics and speed of internationalization (Musteen et al., 2010). Customer collaboration and collaborative knowledge management in small and medium businesses can improve marketing performance (Fidel et al., 2015). The use of information technology in the communication network between companies and customers can support competitive advantage (Sakchutchawan, 2011) H3: Collaborative network significantly affect competitive advantage

\section{Relationship between Collaborative Networks and Performance}

Internal cooperation in small and medium companies can improve innovation performance, on the contrary cooperate with the government cannot improve innovation performance (Zeng et al., 2010), and bonding diverse collaboration (collaborative tie heterogeneity) can improve organizational performance (Ofem, 2014). Entrepreneurial orientation supported by vast network can improve organizational performance (Ofem, 2014). Networks capability significantly moderates the relationship between entrepreneurial orientation and business performance (Zhang \& Zhang, 2012). Collaborative network size has no effect on organizational performance (Ofem, 2014). A strong network structure strengthens the tendency to increase the company's performance (Andrevski, 2009). 
The synergy of diversity within the organization bonds moderate the relationship between entrepreneurial orientation with the performance of the organization, as well as the orientation of the high-powered entrepreneurial vast network will improve organizational performance (Ofem, 2014). Information sharing and incentive as predictors of supply chain performance in small and medium enterprises (Eyaa et al., 2010). Human capital resources have a significant effect on international performance, while the collaborative networkhas no significant effect on the performance of international efforts on small and medium-sized high-tech (Kenny, 2011). Network on small and medium enterprises affect the growth of the company (Sirec \& Brada, 2009). Collaborative communication is able to improve financial performance, the performance of cooperation with customers (Chen et al., 2013).

H4: Collaborative network a significantly affect performance

\section{Relationship between Entrepreneurial Orienta- tion and Performance}

Entrepreneurial orientation and competitive advantage plays an important role in improving corporate performance. Entrepreneurial orientation and competitive advantage are the key success factors of the organization, so the higher the entrepreneurial orientation is, the higher the organizational performance (Zhang \& Zhang, 2012; Farsi et al., 2013; Mahmood \& Hanafi, 2013; Ofem, 2014). Entrepreneurship significantly effects the company's performance and contributes to comprehend the importance of entrepreneurship of entrepreneurship-based resources (Felicio et al., 2012).

Likewise, the high entrepreneurial orientation supported by a vast network will improve organizational performance (Ofem, 2014). Entrepreneurial orientation is able to increase the success of the project (Parkman et al., 2012), and the size of the network moderate the relationship between entrepreneurial orientation with organizational performance (Ofem, 2014).
H5: Entrepreneurial orientation significantly affect performance

\section{Relations between Innovation Capability and Performance}

Innovation, firm size, demographics, location and the experience positively associated with sustained growth for small and medium enterprises (Mirza \& Ali, 2011). The ability to compete in the global market does not only rely on price and quality, but also technology, innovation, creativity (Esti \& Suryani, 2008). The success of innovation is determined by the knowledge, skills and experience of employees to create the added value for the company (Wang \& Wang, 2012), other studies also shows that creativity and innovation impact on the success of small entrepreneurs (Hidayati, 2011). Lowcost strategy (cost leadership) and create differentiationamong others can be a key of competitive advantage (Kuncoro, 2006). The merger of these two concepts will form a marketing strategy called generic strategies, which include: a) the cost leadership b) differentiation c) focus (fee-based or differentiation.

Companies should take into account the impact of the financial and economic risks of management decisions, particularly investment, operational and financing in determining the business performance (Kuncoro, 2006). Creative and innovative organization is able to improve the individuals and organizations performance, as well as create a competitive advantage (Liao $\& \mathrm{Wu}, 2010)$. Product and process innovation affect the performance, while the market cannot improve the innovation performance (Rosli \& Syamsuriana, 2013). The higher the creativity innovation is the higher organizational performance (Tatik 2009; Salim, 2011; Mulyana \& Sutapa, 2014).

Innovation capabilities can improve the success of the project and mediates the relationship between entrepreneurial orientations with the success of the project (Parkman et al., 2012). The entrepreneurial orientation (innovativeness, riskiness, autonomy) is able to improve the innovation, while pro-activeness and 
Mulyana \& Sutapa / The Impact Of Entrepreneurial Orientation and Collaborative Networks ...

aggressive competitive cannot improve innovation performance (Khalili et al., 2013).

H6: Innovation capability significantly affect performance

\section{Relationships between Competitive Advantage and Performance}

The sustainable competitive advantage is a key to successful long-term business performance for the company. Competitive advantage is done by increasing customer value higher than any other company. Competitive advantage is created through a strong brand, comprehensive product line, global marketing network and brand advantages (Chang, 2013). Improved export performance can be effective by understanding the market, establishing distribution network (Brouthers et al., 2009), and the right competitive strategy can encourage the achievement of business performance (Halim, 2011).

There was a significant correlation between the ability of management and organizational performance (Shu Hung, 2012), the competitive advantage mediates the relationship entrepreneurial orientation and entrepreneurial performance (Mahmood \& Hanafi, 2013), and internal resources increase both competitive advantage and performance (Raduan et al., 2010). Competitive advantage mediates the relationship capital intellectual and financial performance (Nixon et al., 2011), the performance of high-tech as strong predictor for competitive advantage (Mohammad et al., 2014).

Competitive advantage moderates learning relationship orientation and business performance (Louis, 2012). Measurement of company performance will be defined on how large companies dominate the market and goal and financially oriented. The company's performance can be measured by some indicators: growth in market share, sales growth, profit growth and Return on Assets (Dibrell \& Davit, 2008). Competitive advantage will improve business performance (Lakhal, 2009; Suzana, 2014; Mulyana \& Sutapa, 2014).

H7: Competitive advantage significantly affect performance.

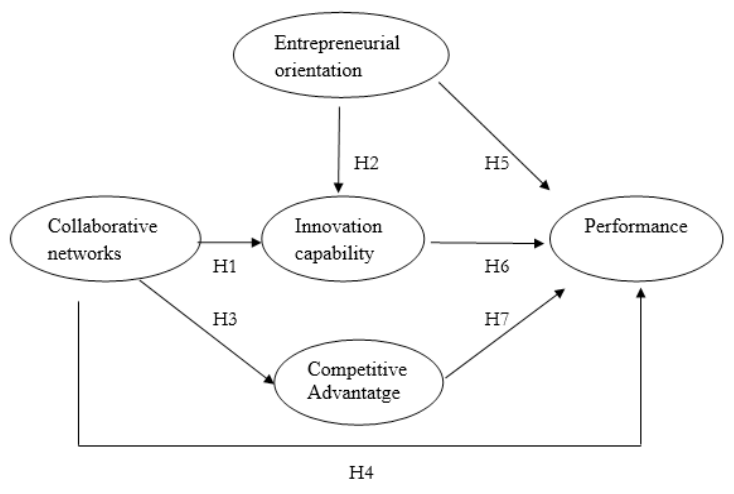

Figure 1. Framework for Thinking

\section{METHOD}

This research analyzes the relationship between variables and methods through a quantitative approach. The goal of this study is to examine the effect of collaborative networks and entrepreneurial orientation towards innovation capabilities and competitive advantages as well as its impact on the performance of the creative industries. The population is combination of all the elements or people who have similar characteristics that became the center of attention by researchers because it is seen as a research environment, while the sample is a subset of a population, made up of some members of the population (Ferdinand, 2011).

Population used in this study is all creative industries focused on the fashion sector in the northern coast of Central Java, since each creative industry developments in these areas have not been evenly distributed. The sources of the data of this study included primary and secondary data. The primary data obtained directly from the source, namely creative industries, while secondary data obtained from various agencies or media as a reference supporting research activities.

The sampling technique used in this study is purposive sampling method by selecting 6 regencies with many fashion creative industries sector and the total sample is 114 respondents. Then, each of the variable and indicator are tested by validity and reliability test. The scale of measurement used is Likert scale with a score of 
1 to $5(1=$ strongly disagree, and $5=$ Strongly Agree). In this study, the data obtained will be analyzed by multiple linear regressions.

As for operational research variables as follows: collaborative network is the ability to understand the company to build a network with external partners that support in increasing innovation capabilities, competitive advantage and performance. The indicators used in this study refers to the results of research (Tsi, 2009; Zeng et al., 2010; Najib et al., 2014): suppliers, industry players/ competitors, buyers and government. Entrepreneurial orientation is the view that underlies a person to create the creativity and innovation and have the independence and courage to take risks, while the indicators used to refer to the results of the study (Lee \& Hsieh, 2010; Farsi et al., 2013; Khalili et al., 2013; Karacaoglu et al., 2013), namely innovativeness, riskiness, pro-activeness, aggressive competitiveness, and autonomy.

Innovation capabilities is the ability to apply creativity in order to solve the problems and opportunities to improve performance, and the indicators used refer to the results of research (Fen Lin, 2007; Tatik 2008; Lee \& Hsieh, 2010; Najib et al., 2014), are packaging innovation, market innovation, product innovation, process innovation. Competitive advantage is the ability to act better than other companies the same industry environment.

The indicators used refer to the results of research (Kuncoro, 2006; Ong et al., 2010; Wingwon, 2012; Parkman et al., 2012; Mahmood \& Hanafi, 2013), namely price / low cost, customer relationship, creativity innovation, difference. Performance is the company's ability to achieve the targets set by the company, and the indicators used refer to the results of research are (Dibrel 2010; Wingwon, 2012; Karacaoglu et al., 2013), the return on assets, earnings growth, sales growth, market share growth.

\section{Analysis Results}

Data analysis method used in this study is quantitative data analysis. This analysis is done to provide information for the researcher, so that the data should be processed and analyzed as basis for decision making. The purpose of the method of data analysis is to interpret and draw conclusions from data obtained. The results of the data analysis are as follows:

\section{Validity Test}

Validity test is used to measure whether questionnaires are valid or not (Ghozali, 2007). A questionnaire considered valid when the questions can reveal something that will be measured by the questionnaire. The level of validity can be measured by comparing count $r$ value (correlation item total correlation) with $\mathrm{r}$ Table with the provisions of degree of freedom (df) $=\mathrm{n}-2$, where $\mathrm{n}$ is the number of samples with $\alpha=5 \%$. Data validity test results can be seen in Table 1.

Table 1. Results of Validity Test

\begin{tabular}{lcc}
\hline \multicolumn{1}{c}{ Indicator } & $\begin{array}{c}\text { r } \\
\text { count }\end{array}$ & $\begin{array}{c}\text { The level } \\
\text { of sig. }\end{array}$ \\
\hline Suppliers & 0.783 & 0.00 \\
Competitor/industry & 0.858 & 0.00 \\
player & & \\
Buyers & 0.851 & 0.00 \\
Government & 0.552 & 0.00 \\
Innovativeness & 0.768 & 0.00 \\
Riskiness & 0.857 & 0.00 \\
Proactiveness & 0.853 & 0.00 \\
Agresive competitiveness & 0.760 & 0.00 \\
Autonomi & 0.575 & 0.00 \\
Packaging innovation & 0.741 & 0.00 \\
Market innovation & 0.880 & 0.00 \\
Product innovation & 0.778 & 0.00 \\
Process innovation & 0.657 & 0.00 \\
Price/low cost & 0.692 & 0.00 \\
Creativity innovation & 0.822 & 0.00 \\
Customer relationship & 0.712 & 0.00 \\
Difference & 0.689 & 0.00 \\
Return on Assets (ROA) & 0.761 & 0.00 \\
Profit growth & 0.806 & 0.00 \\
Sales growth & 0.802 & 0.00 \\
Market share growth & 0.776 & 0.00 \\
\hline
\end{tabular}

Criteria for the validity of the test as follows: when the value of $r_{\text {coun }}>r_{\text {Table }}$ or the significance value $<0.05$ means it is a valid indicator, 
Mulyana \& Sutapa / The Impact Of Entrepreneurial Orientation and Collaborative Networks ...

whereas if the value of $\mathrm{r}_{\text {coun }}<\mathrm{r}_{\text {Table }}$, or the significance value $>0.05$ means that the indicators is no valid. Validity test results in Table 1 above shows take it all otherwise valid indicator because it has a significance value below 0.05 or $\mathrm{r}$ count $>$ r Table (0.1824).

\section{Reliability Test}

Reliability test is used to measure a questionnaire which is an indicator of a variable or construct (Ghozali, 2007). A questionnaire is reliable when statement's respondents are consistent over time. The higher the level of reliability of a measuring device is the more stable it also gauges.

The results in Table 2 shows that all variables are reliable since the Cronbach Alpha value ( $\alpha$ ), a construct has a Conbarch Alpha value $>0.60$.

Table 2. Results of Reliability Test

\begin{tabular}{lc}
\hline \multicolumn{1}{c}{ Variable } & $\begin{array}{c}\text { Cronbach } \\
\text { Alpha }\end{array}$ \\
\hline Collaborative networks & 0.759 \\
Entrepreneurial orientation & 0.821 \\
Innovation Capabilities & 0.733 \\
Competitive advantage & 0.707 \\
Performance & 0.794 \\
\hline
\end{tabular}

\section{Classic Assumption Test}

Classic assumption test was done through several steps, among others, multicolinearity test, normality test, and test heteroskedasticity. Multicolinearity test is useful to determine whether the proposed regression model has found a correlation between independent variables. A good model should not have correlation between independent variables. To identify the presence of multicollinearity can be done by finding the amount of variance inflaction factor (VIF). If the VIF value of less than ten (10) and the tolerance value of more than 0.1 means that the regression is free from multicolinearity.

The second classic assumption test is normality test. The purpose of normality test is to determine whether or not the variables are normally distributed. As in this study, normality of residual non-parametric tests used is Kolmogorov-Smirnov. If the value of significance is more than 0.05 , means that residual data is normally distributed and vice versa (Ghozali, 2007). Data processing results show that the value $0.509>0.05$, so that the residual data is normally distributed. The last classic assumption test is heteroskedasticity test. Heteroskedasticity test is to determine whether a variant regression from one observation to another observation.

When the variance of the residuals is different from other observations, it means that it is heteroskedasticity. If independent variable significantly affects the dependent variable, then there is any indication of heteroscedasticity (Ghozali, 2007). Glejser test results show a significant value for the collaborative networks variable is 0.190 entrepreneurial orientation is 0.958 , innovation capabilities 0.128 and competitive advantage is 0.633 . The results of this study show that none of the independent variables are statistically significant in influencing variables to the dependent, so there were not heteroskedasticities.

\section{RESULT AND DISCUSSION}

Multiple linear regression analysis will be used to test the effect of various independent variables on the dependent variable. The results of the analysis shown in Table 3.

In the first regression model, the results of data analysis on innovation capabilities (Y1) and collaborative networks (X1) and the entrepreneurial orientation (X2). The results shows regression coefficient value of collaborative networks of independent variables (X1) is 0.131 with a significance level below 0.05 , so the $\mathrm{H} 1$ is accepted, meaning the more comprehensive and effective collaborative networks, the high innovation capabilities. The regression coefficient variable of entrepreneurial orientation is 0.796 with a significance level below 0.01 , so $\mathrm{H} 2$ is accepted, meaning that the higher the entrepreneurial orientation is, the higher inno- 
Table 3. Regression Analysis

\begin{tabular}{lccc}
\hline & \multicolumn{3}{c}{ Dependent Variable } \\
\cline { 2 - 4 } & $\begin{array}{c}\mathbf{1}^{\text {st }} \text { Model } \\
\text { Regresion }\end{array}$ & $\begin{array}{c}\mathbf{2}^{\text {nd }} \text { Model } \\
\text { Regresion }\end{array}$ & $3^{\text {rd }}$ Model Regresion \\
\hline \multicolumn{1}{c}{ Independent Variable } & $\begin{array}{c}\text { Innovation } \\
\text { capabilities (Y1) }\end{array}$ & $\begin{array}{c}\text { Competitive } \\
\text { advantage (Y2) }\end{array}$ & Performance (Y3) \\
\hline -Collaborative network (X1) & $0.131^{* *}$ & $0.719^{*}$ & 0.040 \\
-Entrepreneurial orientation (X2) & $0.796^{*}$ & & $0.255^{*}$ \\
-Innovation capabilities (Y1) & & & $0.377^{*}$ \\
-Competitive advantage (Y2) & 0.800 & $0.331^{*}$ \\
\hline -Adjusted R Square & & & \\
-Adjusted R Square & & & 0.911 \\
-Adjusted R Square & & & \\
\hline Information: & & &
\end{tabular}

*) Significant 0.01 ; $^{* *}$ ) Significant 0.05

vation capabilities. While Adjusted R Square obtained a value is 0.800 means innovation capabilities can be explained by the collaborative networks and entrepreneurial orientation of $80.0 \%$ and the rest is explained by other variables outside the research model.

In the second regression model, analysis of competitive advantage (Y2) and collaborative networks (X1) indicates the value of regression coefficient of 0.719 with a significance level below 0.01 , so $\mathrm{H} 3$ is accepted, meaning that the more comprehensive and effective collaborative networks that carried, the more company can create a competitive advantage.

In the third regression model, the results of the analysis of performance and collaborative networks $(\mathrm{X} 1)$, entrepreneurial orientation (X2), the innovation capability (Y1) and competitive advantage (Y2). The results show the regression coefficient of collaborative networks is 0.040 with significance above 0.05 , so $\mathrm{H} 4$ is rejected. Then the regression coefficient of entrepreneurial orientation is 0.255 with a significance level below 0.01 , so H5 is accepted.

This condition indicates that the higher entrepreneurial orientation is the higher performance. Regression coefficient of innovation capabilities is 0.377 with a significance level below 0.01 , so that $\mathrm{H} 6$ is accepted, meaning that the higher innovation capability is the higher per- formance. Furthermore, the regression coefficient of competitive advantage variable is 0.331 with a significance level below 0.01 , so $\mathrm{H} 7$ is accepted. This condition indicates the higher the competitive advantage is the higher company performance.

The results also show that collaborative networks affect performance through innovation capabilities. Based on the statistical test, direct influence of the collaborative networks on performance shown by coefficient regression of 0.040 (not significant), whereas the indirect effect (through innovation capabilities) has regression coefficient of 0.049 ( $0.131 \mathrm{X} 0.377$ ). The value regression coefficient of the indirect affect is greater than the direct affects, thus the innovation capabilities as an intervening variable. The result show that collaborative networks affect performance through innovation capabilities.

Likewise, collaborative networks affect performance through competitive advantage. Statistical analysis showed the magnitude of the indirect affect regression coefficient of collaborative networks on the performance (via a competitive advantage) is 0.237 ( $0.719 \times 0.331)$, while the direct influence is 0.040 (not significant). The value of the indirect effect is greater than the direct effect, so that more comprehensive and effective collaborative networks that 
Mulyana \& Sutapa / The Impact Of Entrepreneurial Orientation and Collaborative Networks ...

built the company will create more competitive advantage and performance.

The results also demonstrate that entrepreneurial orientation affect on performance through innovation capabilities. Based on the statistical analysis, it shows that regression coefficient of direct influence of entrepreneurial orientation on the performance of 0.255 , while the indirect influence that entrepreneurial orientation on performance through innovation capabilities is $0.300(0.796 \mathrm{X} 0.377)$. The value of the indirect effect is greater than the direct effect, thus getting stronger entrepreneurial orientation, the more innovation capabilities and performance improvement.

The value of Adjusted R Square is 0.911 indicates that the performance related to collaborative networks, entrepreneurial orientation, innovation capabilities and competitive advantage is $91.1 \%$ and remaining explained by other variables outside the research model.

\section{The Effect of Collaborative Networks on Inno- vation Capabilities \\ Collaborative networks significantly ef-} fect the development of innovation (Zheng \& Zhao, 2013; Najib et al., 2014). Collaborative networks have the potential to build synergy in the technological innovation development (Ziemer, 2009). The dynamics of business relationships are very complex and encourage companies improve their strategic collaboration to develop innovations that can generate value for each member (Sakmoto et al., 2010). Collaborative networks are designed to define an innovation strategy to assess the competence of partners' external network that includes universities, companies, and governments (Carayannis \& Campbell, 2009; Varrichio et al., 2012)

Collaborative networks are built by the creative industries by developing support from suppliers, buyers, competitors and government. Establishing a good cooperation with suppliers is required to support the availability of raw materials and the sustainability of the production process. Furthermore, to increase sales company should develop cooperation between the creative industries with buyers, as well as establishing cooperation with competitor /industry players (community) for sharing information that encourages innovation capabilities. While cooperation with the government is done through coaching, guidance, supervision, training, that can improve innovation capabilities.

This results are also in line with collaborative networks develop network model for the innovation development, which includes four variables that describe a collaborative network, including suppliers, clients, competitors, and research organizations (Tsai, 2009, Zeng et al., 2010). A good collaborative networks are able to increase the innovation capability, includes market, product and packaging innovation. The organization innovation describes business cooperation in connecting people, ideas and resources that to produce creativity and innovation.

\section{The Effect of Entrepreneurial Orientation on Innovation Capabilities.}

Entrepreneurial orientation significantly effects innovation capabilities. The study's findings are in line with research found that entrepreneurship has direct effect on marketing capabilities, innovation capabilities (Lee \& Hsieh, 2010) and entrepreneurial orientation were able to improve innovation performance (Parkman et al., 2012; Khalili et al., 2013; Farida, 2016).

Several studies found that entrepreneurial orientation have important role in enhancing innovation capabilities. The study of social capital entrepreneur can improve concentration and awareness of the complexity of the innovation model (Xu Yang, 2011). Management support entrepreneurial-oriented companies to innovate (Maatoofi \& Tajedddini, 2011). Autonomy in decision making, facilitate businesses more aggressive and proactive in competing. Autonomy is also able to accelerate the decisionmaking business risk as well as the courage to innovate (products, markets, processes, packaging), as a step to improve innovation capabilities. 
The Effect of Collaborative Networks on Competitive Advantage

Collaborative networks have a significant effect on competitive advantage. The results of this study are in line with the findings of the study that the network connection through the incorporation of knowledge, skills and resources can build competitive advantage through specialization, collaboration and increased flexibility (Kolakovic \& Milovanovic, 2010), and collaborative communication can improve the capability of marketing and capacity of market relations (Chen et al., 2013). On the contrary collaborative networks in the SMEs food has no significant effect on the competitive advantage (Najib et al., 2014).

Competitive advantage shows that a company can do better than other companies even if they are in same industrial environment (Hassan, 2009). Improving competitive advantage can be done bymaking lower prices than the competition, as well as the creating more innovative products. Besides, the creation of different new products and build good relationships with customers can encourage the creation of competitive advantage.

Other studies shows thatsocial networking as a marketing strategy for small and medium enterprises (Vasques, 2014), and as a competitive force that is determined by the interaction of the actors in networks (Awauh, 2008). External and internal knowledge sharing networks are able to create an excellence corporate (Kennel \& Giround, 2015). Customer collaboration and collaborative knowledge management in small and medium businesses can improve marketing performance (Fidel et al., 2015).

\section{The Effect of Collaborative Networks on Perfor- mance}

Collaborative network has no significant effect on performance. This finding is in line previous studies showed that internal cooperation in small and medium companies can improve innovation performance, on the contrary cooperate with the government cannot improve innovation performance (Zeng et al., 2010), and collaborative network size has no effect on organizational performance (Ofem, 2014). The results of this study contradict with the findings of the previous studies that the bonding of diverse collaboration (collaborative tie heterogeneity) can improve organizational performance (Ofem, 2014) and a strong network structure will strengthen the tendency to increase the performance of the company (Andrevski, 2009).

These results indicate that the effect of collaborative networks on the performance through innovation capabilities, thus extensive collaborative networks and which is supported by strong innovation capabilities can improve performance. Moreover, collaborative networks affect performance through excellence competition, means that extensive collaborative networks can create competitive advantage and affectin improving performance. Entrepreneurial orientation effect on performance through innovation capabilities, so the higher the entrepreneurial orientation is the higher innovation capabilities and can also affects performance.

Establishing collaborative networks in the creative industry can be done by developing a good cooperation with suppliers, buyers, competitors and government. Moreover, it also requires good relation with suppliers to support the availability of raw materials and the sustainability of the production process. Building a good relationship with buyers can boost sales, as well as establishing cooperation with competitor in providing information exchange that encourages innovation capabilities and performance. Helping collaboration, coaching, mentoring will encourage efficiency and effectiveness of the work which can boost performance.

The results are in line with findings that networking on small and medium enterprises effect on the growth of the company (Sirec \& Brada, 2009) and collaborative communication can improve financial performance, cooperation performancewith customers (Chen et al., 2013).

The others results of other studies show that a high entrepreneurial orientation supported a vast network which can improve organizational performance (Ofem 2014). Networks capability 
Mulyana \& Sutapa / The Impact Of Entrepreneurial Orientation and Collaborative Networks ...

significantly moderates the relationship between entrepreneurial orientation and business performance (Zhang \& Zhang, 2012).

\section{The Effect of Entrepreneurial Orientation on Performance}

Entrepreneurial orientation significantly effects performance. The results of this research is still in line with the research findings stating that the entrepreneurial orientation and competitive advantage are key success of the organization, so the higher the entrepreneurial orientation is the more organizational performance improve (Zhang \& Zhang, 2012; Mahmood \& Hanafi, 2013; Farsi et al., 2013; Ofem, 2014). Entrepreneurial orientation and competitive advantage plays an important role in improving corporate performance.

Autonomy in makingdecision can make business isfaster and easier in being more aggressive and proactive. It is also can make decision faster in taking into account the business risks that can effect on performance. The continuous entrepreneurial skills in making innovation are expected to improve performance. This study findingsare also in line with the finding that entrepreneurship effect the company performance (Felicio et al., 2012). Likewise, the high entrepreneurial orientation supported by a vast network will improve organizational performance (Ofem, 2014). Entrepreneurial orientation is able to increase the success of the project (Parkman et al., 2012).

\section{The Effect of Innovation Capabilities on Perfor- mance}

Innovation capabilities have a significant effect on performance. The results are in line with the findings of research confirming that the higher creativity innovation, the more organizational performance (Tatik 2009; Salim, 2011; Mulyana \& Sutapa, 2014). Product innovation and process innovation can improve the performance (Rosli \& Syamsuriana, 2013), and the creativity and innovation affects the success of small entrepreneurs (Hidayati, 2011). Another study also stated entrepreneurial orientation (innova- tiveness, riskiness, and autonomy) can improve innovation performance (Khalili et al., 2013).

The location innovation and the experience positively associated with sustained growth for small and medium enterprises (Mirza \& Ali, 2011). The ability to compete in the global market is not only on price and quality, but also technology, innovation, creativity (Esti \& Suryani, 2008). The ability of the company in implementing product, process, market, and packaging innovation encourage the creation of competitive advantage, so it can impact on sales performance improvement. In line with the statement, that the cost leadership and differentiation can be a key of competitive advantage (Kuncoro, 2006). The success of innovation is determined by the knowledge, skills and experience in adding value for the company (Wang \& Wang, 2012).

\section{The Effect of Competitive Advantage on Perfor- mance}

Competitive advantage significantly effect on performance. The results are line with the findings of research which states that competitive advantage can improve business performance (Lakhal, 2009; Suzana, 2014; Mulyana \& Sutapa, 2014). Competitive advantage is the key factor in creating long-term business performance for the company. Competitive advantage is created by having products innovative and cheaper price than other companies in the same industry. Moreover, making good relationships with customers can boost sales and market share.

This finding is in line with the results of the study, which states the competitive advantage created through a strong brand, comprehensive product line, global marketing network and brand advantages (Chang, 2013) and the right competitive strategy can encourage business performance (Halim, 2011). Increasing sales, large market share, and profit growth can be achieved by having good relationships with consumers, creating innovative products and competitive prices. These results are in line with findings that the high export performance can be established by understanding the market, 
creating a distribution network (Brouthers et al., 2009), and internal resources increase both competitive advantage and performance (Raduan et al., 2010).

\section{CONCLUSIONAND RECOMMENDATION}

A good collaborative network supported by a good innovation capability (product, process, market and packaging) can improve organizational performance. Moreover, a good collaborative network encourages the competitive advantage which can effect on performance. A good entrepreneurial orientation which is supported by innovation capabilities can increase the company performance.

Managerial implication of this research is that in creating innovation capability and competitive advantage needs to make a good collaborative network. Improved performance can be realized by creating collaborative networks which are supported by innovation capabilities and competitive advantage. Moreover, performance improvement can be done by creating a strong entrepreneurial orientation and innovation capabilities supported by the business operators.

The theoretical implication of this research is that the creative industrial performance can be improved by building a good collaborative network and supported by innovation capabilities and competitive advantage. Creative industry performance can be improved by strengthening the entrepreneurial orientation which is supported by innovation capabilities. The results of this study are expected to strengthen the development of science, especially in the field of management. Limitations of this study only is the use of small sample (114 respondents) coming from various districts/ cities in the northern coast of Central Java, so the result is not optimal and for the future research is expected to examine the size networks, social networks.

\section{REFERENCES}

Awauh, G. B. 2008. Networked (Interactive) Position: A New View Of Developing and Sus- taining Competitive Advantage. Competitiveness Review: An International Business Journal. 18 (4): 333-350.

Andrevski, G. 2009. Competitive Strategi, Alliance Networks and Firm Performance. Unpublished Dissertations. UMI: University of Kentucky.

Alfonso, O \& Monteiro, S \& Thomson, M. 2010. A Growth Model for the Quadruple Helix Innovation Theory. Journal of Business Economics and Management. 13 (4): 1-31

Boland. W. P., Phillips, P. W. P., Ryan, C. D \& Knowles, S. M. 2012. Collaboration and the Generation of New Knowledge in Networked Innovation Systems: A Bibliometric Analysis. Procedia-social and Behavioral Science, $10^{\text {th }}$ Triple Helix Conference. 52: 15-24.

Chen, C. C., Li, P. C \& Arnold, T. J. 2013. Effects of Collaborative Communication on the Development of Market-Relating Capabilities and Relational Performance Metricsin Industrial Markets. Industrial Marketing Management. 42: 1181-1191.

Chang, H. J. 2013. A Case Study on the Model of Strategic Entrepreneurship. The International Journal of Organizational Innovation. 5 (4): 30-44.

Carayannis, E. G \& Campbell D. F. J. 2009. Knowledge Creation, Diffusion and Use in Innovation Network and Knowledge Cluster: A Comparative System Approach Across the United State, Europe and Asia. London: Preager.

Dibrell, C \& Davit, P. S. 2008. Fueling Innovation Trough Information Technology In SMEs. Journal of Small Business Management. 46 (2): 203-218.

Doina, P., Sebastian, C \& Eduard, C. 2012. Alliances and Competitive Advantage. International Journal of Information and Education Technology. 2 (5): 533-534.

Brouthers, L. E., Nakos, G., Hadjimarcou, J \& Brouthers, K. D. 2009. Key Factors for Successful ExportPerformance for Small Firms. Journal of International Marketing. 17 (3): 21-38

Eyaa, S., Ntayi, J. M \& Namagembe, S. 2010. Collaborative Relationship and SME Supply Chain Performance. World Journal of Enterprenuership, Management and Sustainable Development. 6 (3): 233-145.

Everingham J. A., Warburton, J., Cuthill, M \& Bar- 
Mulyana \& Sutapa / The Impact Of Entrepreneurial Orientation and Collaborative Networks ...

tlett, H. 2011. Collaborative Governance of Ageing: Challenges for Local Government in Partnering with the Seniors' Sector. Local Government Studies. 1: 1-21

Esti, R. K \& Suryani, D. 2008. Potret Industri Kreatif Indonesia. Economic Review. 212.

Ferdinand. A. 2011. Metode Penelitian Manajemen. Semarang: Penerbit BP.UNDIP

Farida, N. 2016. Determinants of Marketing Performance: Innovation, Market Capabilities and Marketing Performance. Jurnal Dinamika Manajemen. 7(1): 56-65.

Farsi. J. Y., Rezaadeh, A \& Najmabad, A. D. 2013. Social capital and Organizational Innovation: The Mediating effect of Entrepreneurial Orientation. Journal of Community Positive Practices. 13 (2): 22-40.

Felicio. J. A., Rodrigus, R \& Caldeirinha, V. R. 2012. The Effect of Intrapreneurship on Corporate Performance. Management Decision. 50 (10): 1717-1738.

Fidel. P., Schlesinger, W \& Cervera, A. 2010. Collaborating to Innovate: Effects on Customer Knowledge Managementand Performance. Journal of Business Research. 68: 1426-1428.

Fen Lin. H. 2007. Knowledge Sharing and Firm Innovation Capability: An Empirical Study. International Journal of Manpower. 28 (3/4): 315-332.

Ghozali, I. 2007. Aplikasi Analisis Multivariat dengan Program SPSS. Semarang: Penerbit UNDIP.

Hasan, A. 2008. Marketing. Yogyakarta: MedPress.

Halim, A. 2011.The Measurement of Entrepreneurial Personality and BusinessPerformance in Terengganu Creative Industry. IntemationalJoumal of Business and Management. 6: 183188.

Hidayati, E. 2011. Kreativitas dan Inovasi Berpengaruh Pada Kewirausahaan Kecil. Jurnal Manajemen dan Kewirausahaan. 13 (1): 8-16

Kim, Y \& Lui, S. S. 2015. The Impact of External Network and Business Group on Innovation: Do the Types of Innovation Matter ?. Journal of Business Research. 68: 1964-1973

Khalili, H., Nedjadhuseein, S \& Fazel, A. 2013. The Influence of Entrepreneurial Orientation on Innovative Performance Study of a Petrochemical Company in Iran. Journal of Knowledge-based Innovation in China. 5 (3): 262-270.

Kuncoro, M. 2006. Strategi Bagaimana Meraih Ke- unggulan Kompetitif. Jakarta: Erlangga.

Kenny. B. 2011. Network Resources and International Performance of Hightech SMEs. Journal of Small Business and Enterprise Development. 18 (3): 529-555.

Kolakovic, M \& Milovanovic, B. J. 2010. Strategic Networking as a Driver of Competitiveness of Croation Small and Medium Entreprises. International Conference Proceeding. 3 (13): 1213-1224.

Kennel, J. S \& Giround, A. 2015. MNEs and FSAs: Network knowledge, strategic orientation and performance. Journal of World Business. 50: 94-107

Karacaoglu, K., Bayrakdaroglu, A \& San, F. B. 2013. The Impact of Corporate Entrepreneurship on Firms' Financial Performance: Evidence from Istanbul Stock Exchange. International Business Research. 6 (1): 163-175.

Louis. A. M. 2012. The Relationship Between Learning Orientation And Business Performance And The Moderating Effect Of Competitive Advantage: A Service Organization Perspective. Journal of Service Science. 5 (1): 43-58

Lakhal, L. 2009. Impact of quality on competitive advantage and organizational performance. Journal of the Operational Research Society. 6 (1): $637-645$

Liao, S \& Wu, C. 2010. System Perspective of Knowledge Management, Organizational Learning, and Organizational Innovation. Expert Systems with Applications. 37 (3): $1096-1103$.

Lee, J. S \& Hsieh, C. J. 2010. A Research in Relating Entrepreneurship, Marketing Capabilitay, Innovative Capability and Sustained Competitive Advantage. Journal Business and Economic Research. 8 (9): 109-119.

Mirza, W. A \& Ali, B. 2011. The Dilemma of Knowledge Management, Innovation and Entrepreneurship in SME's: an Empirical Study. Interdisciplinary Journal of Contemporary Research in Business. 3 (2): 1112-1128.

Musteen, M., Francis, J \& Datta, D. K. 2010. The Influence of International Networks on Internationalization Speed Andperformance: A Study of Czech SMEs. Journal of World Business. 45 (2): 197-205.

Mahmood, O. Y. A \& Hanafi, N. 2013. Entrepreneurial Orientation and Business Perfor- 
mance of Women-Owned Small and Medium Enterprises in Malaysia: Competitive Advantage as a Mediator. International Journal of Business and Social Science. 4 (1): 8290.

Mulyana \& Sutapa. 2014. Peningkatan Kapabilitas Inovasi, Keunggulan Bersaing dan Kinerja Melalui Pendekatan Quadruple Helix. Jurnal Manajemen Teknologi. 13 (3): 304-321

Maatoofi, A. R \& Tajedddini, K. 2011. Effect of Market Orientation and Entrepreneurial Orientation on Innovation Evidence from Auto Parts Manufacturing in Iran. Journal of Management Research. 11 (1): 20-30.

Mohammad, S., Ahamadi, Z. A \& Adnan, M. A. 2014. Technology Transfer Performance and Competitive Advantage, Evidence from Yemen. Asia Social Science. 10 (3): 194-204.

Nixon, K., Ahiauzu, A \& Ntayi, J. M. 2011. Competitive Advantage: Mediator of Intellectual Capital and Performance. Journal of Intellectual Capital. 12 (1): 152-164.

Najib, M., Dewi, F. R \& Widyastuti, H. 2014. Collaborative Networks as a Source of Innovation and Sustainable Competitiveness for Small and Medium Food Processing Enterprises in Indonesia. International Journal of Business and Management. 9 (9): 147-160.

Ong, J. W., Ismail, H \& Goh, G. G. G. 2010. The Competitive Advantage of Small and Medium Enterprises (SMEs): The Role of Entrepreneurship and Luck. Journal of Small Business and Entrepreneurship. 23 (3): 373-391.

Ofem, B. 2014. Intrepreneurial Orientation, Collaborative Networks and Non profit Performance. Unpublished Dissertations. Kentucky: University of Kentucky.

Parkman, I. D., Holloway, S. S \& Sabastiao, H. 2012. Creative industries: Aligning Entrepreneurial Orientation and Innovation Capacity. Journal of Research in Marketing and Entrepreneurship. 14 (1): 95-114.

Paulina, I \& Wardoyo. 2012. Faktor Pendukung terhadap Intensi Berwirausaha pada Mahasiswa. Jurnal Dinamika Manajemen. 3 (1): 1-10.

Raduan, C., Abdullah, H \& Ismail, A. 2010. A Review on the Relationship between Organizational Resources, Competitive Advantage and Performance. The Journal of International Social Research. 3 (11): 489-498.

Rosli, M \& Syamsuriana, S. 2013. The Impact of
Innovation on the Performance of Small and Medium Manufacturing Enterprises. Journal of Innovation Management in Small \& Medium Enterprise. 2 (3): 1-16.

Sakmoto, A., Roper, S., Vasconcellos, M. A \& Gobbo Jr, J. A. 2010. Innovation in Collaborative Networks of Small and Medium Enterprises: An Interpretative Approach. Proceedings. Presented at the International Council for Small business (ICSB), Cincinnati, Ohio, USA. 1-20

Sirec, K \& Brada, B. 2009. How does Networking Impact the SMEs Growth. Reseacrch Paper. 42 (2): 59-65.

Suzana, N. R \& Millar, H. 2014. Exploring the Relationships among Sustainable Manufacturing Practices, Business Performance and Competitive Advantage: Perspectives from a Developing Economy. Journal of Management and Sustainability. 4 (3): 37-53.

Shu Hung, S. 2012. The Relationship Between Learning Orientation And Business Performance And The Moderating Effect Of Competitive Advantage: A Service Organization Perspective. The Journal of Human Resource and Adult Learning. 8 (2): 42-49.

Sakchutchawan, S. 2011. Innovation and Competitive Advantage: Model andImplementation for Global Logistics. International Business Research. 4 (3): 10-21.

Sousa, F. C. 2012. Creativity, Innovation and Collaborative Organizations. TheInternational Journal of Organization Innovation. 5 (1): 26-64.

Salim. I. M. 2011. Organizational Learning, Innovation, and Performance: A Study of Malaysian Small and Medium Sized Enterprises. International Journal of Business and Management. 6 (12): 118-125

Tsai, K. H. 2009. Collaborative Networks and Product Innovation Performance. Research Polecy. 38 (5): 765-778.

Tatik, N. 2009. Orientasi Entrepreneur dan Modal Sosial: Strategi Peningkatan Kinerja Organisasi. Desertasi. UNDIP. Semarang.

Vasques, G. A. N. 2014. Best practice in the use of social networks marketing strategy as inSMEs. Procedia - Social and Behavioral Sciences. 148: 533 - 542.

Varrichio, P., Diogenes, D., Jorge, A \& Garnica, L. 2012. Collaborative Network and Sustain- 
Mulyana \& Sutapa / The Impact Of Entrepreneurial Orientation and Collaborative Networks ...

able Bussiness: A Case Study in The Brazilian System of Innovation. 10th Triple Helix Conference. Procedia-Social and Behavioral Sciences. 52: 90-99.

Wingwon, B. 2012. Effects of Entrepreneurship, Organization Capability, Strategic Decision Making and Innovation toward the Competitive Advantage of SMEs Enterprises. Journal of Management and Sustainability. 2 (1): 137150.

Wang, Z \& Wang, N. 2012. Knowledge Sharing, Innovation and Firm Performance. Expert Systems with Applications. 39 (10): 8899-8908.

Xu Yang. 2011. Entrepreneurial social capitaland cognitive model ofinnovation. Management Research Review. 34 (8): 910-926. DOI 10.1108/01409171111152510.
Zeng, S. X \& Xie, X. M \& Tam, C.M. 2010. Relationship Between Cooperation Networks and Innovation Performaance of SMEs, Technovation. 30 (3): 181-194.

Zhang, Y \& Zhang, X. 2012. The effect of entrepreneurial orientation on business performance. A role of network capabilities in China. Journal of Chinese Entrepreneurship. 4 (2): 132142.

Ziemer, N \& Long. S. 2009. Collaborative Networks as Innovation Accelerators. Proceedings of the Industrial Engineering Research Conference. 391-396

Zheng. X \& Zhao. Y. 2013. The impact of alliance network structure on firm innovation capability. Journal of Science and Technology. 4 (1): 4-19. 